\title{
Revisiting Cambodian PRivate tutoring: INSIGHTS INTO TEACHERS' PROFESSIONAL MISCONDUCT
}

\author{
Sopha Soeung ${ }^{\mathrm{a}}$ \\ Hiroshima University
}

\begin{abstract}
Cambodia uses a 'discouragement' strategy to manage teachers' engagement in supplying private tutoring (PT). However, previous studies have criticised teachers' professional misconduct in terms of promoting tutoring classes to ensure supplementary income. Currently, examination reforms alongside economic growth propose a new understanding of professional misconduct. Based on descriptive data from 93 students and in-depth interviews with 24 informants, who were tutees and their parents, tutors and school administrators respectively, this study found uncaring pedagogies to be a primary motivator for tutoring demand. This tended to have an association with the inadequate instructional time given to core examination subjects and implementation of the learner-based approach. Additionally, the examination reform brought positive changes in the teacher's behaviour. Although this study's findings are largely aligned with previous studies, it still sheds light on new perspectives regarding teachers' professional misconduct in Cambodia.
\end{abstract}

Keywords: Cambodia; shadow education; supplementary tutoring; teaching profession; urban areas

\section{Introduction}

Education is globally acknowledged as public good whereby each government is expected to give very fair treatment to every citizen regardless of their family economic status and background. It is, additionally, an investment for the development of the nation. However, the existence of private tutoring (PT) creates inequality for individuals towards obtaining a quality education in the eyes of educational stakeholders, mainly in countries in which schoolteachers provide fee-paid tutoring. Heyneman $(2009,2011)$ argues that offering PT to the students for whom teachers are responsible in mainstream schools is a corrupt practice in education. This, furthermore, can downplay teaching professional standards and leads to professional misconduct. Due to the great expansion of PT and its impacts, researchers constantly alert educators and policymakers at the international level to take relevant actions towards improving the quality and equality of education (Mori \& Baker, 2010). Each country/region employs different regulations/guidelines to regulate PT. Cambodia, China, Georgia, Lebanon and Nigeria use professional codes of conduct referred to as 'discouragement' to deter teachers from engaging in PT. Other regulations/guidelines namely 'permission if approved' in Brunei Darussalam, Malaysia, Singapore, Vietnam, 'laissez faire' in Hong Kong SAR, Philippines, Thailand and 'officially prohibit' in Bhutan, Japan are also implemented (Bray \& Kwo, 2014; Liu \& Bray, 2020).

\section{Incidence of Private Tutoring and Professional Misconduct}

Biswal (1999, p. 238) reveals prevalent causes of PT in developing countries, namely low salaries, limited accountability and weak monitoring system. For example, teachers engaged in private

a Correspondence can be directed to: soeungsopha@gmail.com 
activities inside mainstream classrooms such as selling snack in the Tanzanian context either for personal benefits or to secure their family's needs (Betweli, 2013, p. 89). There have also been instances where teachers sold test papers, forced parents to pay for PT and in some cases for passing grade adjustments in Southeast Europe, the former Soviet Union as well as in China, Malaysia and Vietnam (Hallak \& Poisson, 2007; 2008; Rumyantseva, 2005). Similarly, in Latin America, teachers forced students to pay if they wanted to move to the next grade (Heyneman, 2009).

Heyneman (2009, p. 3) points these behaviours (i.e., biasing in grading and assessing, forcing students to take tutoring lessons and buy some materials as well as using school properties for personal benefits, etc.) as professional misconduct, and considers it as one of the corrupt ways in education. Similarly, Bray (2003, p. 27) also emphasizes ways in which teachers abuse their position over their students for personal gains as corruption; for example, withholding contents and accepting a bribe to promote students to the next grade. Subsequent literature (i.e., Banfield, Richmond, \& McCroskey, 2006; Kelsey, Kearney, Plax, Allen, \& Ritter, 2004; Zhang, 2007; Zhang, Zhang, \& Castelluccio, 2011) also highlights how professional misconduct interferes in students' learning as well as impacts on parents' trust in teachers' profession and schools (Liu \& Bray, 2020; Page, 2016). Furthermore, professional misconduct spawns not only the poor quality of education at the mainstream schools but also puts students whose families are unable to pay teachers for these extra services at a disadvantage. It, moreover, reduces their opportunity to obtain benefits from this free public good.

\section{Cambodia's Responses Towards Incidence of Private Tutoring}

Cambodia has been committing its best to respond to teachers' low salaries and strengthen its education system. Newly employed upper secondary schoolteachers' basic salaries have been, so far, increased around 68\% during a 10-year time (2010 to 2020) (MoEYS, 2009; 2019a). Yet, teachers claimed that they were unable to meet the family needs due to the simultaneous increase in living costs (Dawson, 2009; Khy, 2019). In 2001, the Cambodian Ministry of Education Youth and Sport (MoEYS) launched the Priority Action Programme (PAP) nationwide to implement a free education policy by abolishing school registration fees and all types of informal payment such as purchasing test papers, learning materials and teachers' gift as well as paying daily fee including tutoring lessons (Bray \& Bunly, 2005; Brehm \& Silova, 2014; Dawson, 2010). It is worth highlighting that MoEYS attempted to stop PT in the mid-1990s (Dawson, 2009). Keng (2009) reports that those programmes and attempts boosted the enrolment rates and further empowered the schools. However, she highlights that schools faced other hindrances such as the PAP program failing to improve the quality of education (pp. 149-150).

Teachers catered for supplementary income by attempting to increase the number of tutees at their tutoring classes by all possible means. Parents feeling concerned about their children's learning and future viewed investing in PT as a necessity (Bray \& Kwo, 2014, p. 27) and a kind of human capital investment (Heyneman, 2011, p. 184). MoEYS amended Articles 13, 17, 25 and 27 of the Ethics Code for the Teaching Profession in 2008 to respond to teacher professional misconduct. These articles address prohibition towards private gains during mainstream school hours as well as forcing students for PT (MoEYS, 2008). These amendments can be linked to the term 'discouragement' defined at the beginning of this paper. However, the main question to be posed is whether this strategy is serving its purpose effectively.

Professional misconduct has been claimed and believed to spawn tutoring demand in Cambodia for more than two decades. However, this paper hypothesizes that the examination reform alongside economic growth may develop new thoughts about professional misconduct towards PT. This new paradigm in Cambodia can be one of the significant examples of tutoring practice in developing countries. This paper attempts to answer the following question through conflating descriptive and narrative information: what are Cambodian twelfth graders' perceptions of teachers' professional misconduct further to the national examination reform? 


\section{Findings on Private Tutoring in Cambodia}

Cambodian MoEYS attempted to ensure equal opportunity in accessing education and obtaining quality education by building more schools, raising teachers' salaries and implementing a free education policy. However, the quality of education shrank further to a rapid increase in school numbers and the inability to supply sufficient qualified teachers (Brehm \& Silova, 2014). Therefore, parents and students demanded PT as a complement to maximize their chances to succeed in the examinations.

There were three main reasons behind Cambodian teachers offering PT namely insufficient instructional time to complete the intended curriculum, large class size and inability to sustain on the government salary (Bray, Kobakhidze, Liu, \& Zhang, 2016; Brehm, Silova, \& Tuot, 2012; Dawson, $2009 ; 2010)$. In this regard, previous studies pointed out some cases of professional misconduct being practised in the Cambodian context. Teachers withhold curriculum contents to secure supplementary income by offering PT to their students (Bray, 1999a; Dawson, 2009). Also, teachers focused more on theories/formula during the mainstream hours but did more practices in PT classes only (Brehm \& Silova, 2014). Some teachers applied effective and caring pedagogies only during PT classes as a strategy to promote demand for PT (Bray, et al., 2016; Bray, Kobakhidze, Zhang, \& Liu, 2018). Bray (2013) pointed out that students who did not pay for PT were likely to repeat their grade because schoolteachers were responsible for designing and rating the end-year examinations. In addition, teachers were more inclined to favour their tutees not only during classroom learning activities but also for examinations by giving them more care, emphasising tests during PT prior to the test date and giving tutees higher scores (Bray, et al., 2016; Bray, et al., 2018; Bray, Liu, Zhang, \& Kobakhidze, 2019; Edwards, Le, \& Sustrarsic, 2019). Some teachers would also allow tutees to cheat during the examinations as well as make fun of non-tutees in class (Maeda, 2019). Conceptually, these cases of professional misconduct from previous literature on PT discussed above mainly combined two aspects, namely teacher's unethical behaviour (e.g., allow tutee to cheat, mock students) and 'uncaring pedagogies' (e.g., withhold contents, teach only theories).

\section{Impacts of Examination Policies and Reform in Cambodia}

Examination eliminating policy is seen as one determinant contributing towards expanding PT demand as well as professional misconduct in Cambodian classroom (Brehm, 2015; Dawson, 2010). In 1997, Cambodia abolished the leaving examination at the primary education level to increase the completion rate of basic education to realise the goals of Education for All. Nevertheless, this policy generated more corrupt practices since class teachers functioned as test designers, exam invigilators and test raters. The elimination of Cambodian sixth grade leaving examination increased the demand towards PT like cases of 'equalisation policies' in South Korea and 'relaxed education' policies in Japan (Dawson, 2010, pp. 21-22). Teachers favoured the students who followed tutoring classes with them. Furthermore, parents thought that their children were likely to fail the grade or be penalized if they did not opt for PT with their class teacher (Bray, 1999b; Bray, 2013).

There are few empirical studies on the impacts of the $12^{\text {th }}$-grade national examination reform since it was launched nationwide in Cambodia in 2014. The main principles of the reform are the legal basis, justice, transparency and accepted results which aim to ensure that only qualified students pass (MoEYS, 2019b). During the year of examination reform, the passing rates of the $12^{\text {th }}$-grade examination sharply declined from $83 \%(2012 / 2013)$ to $26 \%$ (Koyanagi, 2017). However, the passing rates gradually improved in sequential years up to $68.62 \%$ in 2019 (MoEYS, 2019c). It is worth highlighting that result of $12^{\text {th }}$ graders (passed or failed) is just based on how well students perform in the tests during the national examination days. Prior to the examination reform, the achievement from school-based examinations was adjusted and added to the sum scores of the national examination (MoEYS, 2013). Teachers were, thus, able to generate supplementary income through PT by emphasising some parts of tests before the test dates (Brehm, et al., 2012). This practice was seen as an effective strategy to attract students to opt for PT. Those who could afford 
PT thus hoped to maximize their chances for higher scores in the school-based examinations (i.e., monthly tests and semester exams) unlike their peers who could not afford (Bray, et al., 2016; Bray, et al., 2019; Brehm \& Silova, 2014; Edwards, et al., 2019).

In an attempt to eliminate the bribery to cheat during the national examination days, MoEYS doubled the wage of $12^{\text {th }}$-grade examination proctors. Therefore, MoEYS delegated the organisation of the $9^{\text {th }}$-grade national examination to individual schools (Kuch \& Blomberg, 2014). Besides increasing the wage of proctors, MoEYS could save around half of the $9^{\text {th }}$-grade examination budget (Barron, 2014). Nonetheless, Kuch and Blomber (2014) reported that this situation increased more corrupt practices at the mainstream schools resulting in the financial burden going into the hands of households as families are called to invest more in PT while MoEYS is saving on its budget.

\section{Economic Growth in Cambodia}

Recently, Cambodia has been committing towards developing itself into an upper-middle-income country by 2030. After a long economic fluctuation from 1995 to 2009, Cambodia remarkably improved its Gross Domestic Product (GDP) from 6\% (2010) to 7.5\% (2018) (World Bank, 2019). Although its GDP slightly declined by $0.4 \%$ in 2019 , Cambodia maintained its GDP as high as it was in 2014. This GDP increase can be marked as the growth of the middle-class population. Middleclass and rich households tended to demand better quality education (Hanushek \& Wößmann, 2007; Khiev \& Ty, 2011). During the school year 2018/2019, 5.50\% of upper secondary school students attended private schools while $23.51 \%$ of total urban students enrolled in private schools nationwide (MoEYS, 2019d; 2019e). Findings from some countries show household income or family socioeconomic status and urban location as factors influencing demand for PT (Dang, 2013; Dang \& Rogers, 2008; Kwok, 2010).

This study constructs a conceptual framework aiming to assess the significance of the relationship between professional misconduct and PT. Examination reform alongside economic growth is seen as factors that may potentially influence this relationship. Professional misconduct constitutes several elements (see Heyneman, 2009). However, the conceptual framework shown in Figure 1 focuses on two elements of professional misconduct namely: uncaring pedagogies and teacher's unethical behaviour to serve the purpose of this study.

\section{Figure 1. Conceptual Framework}

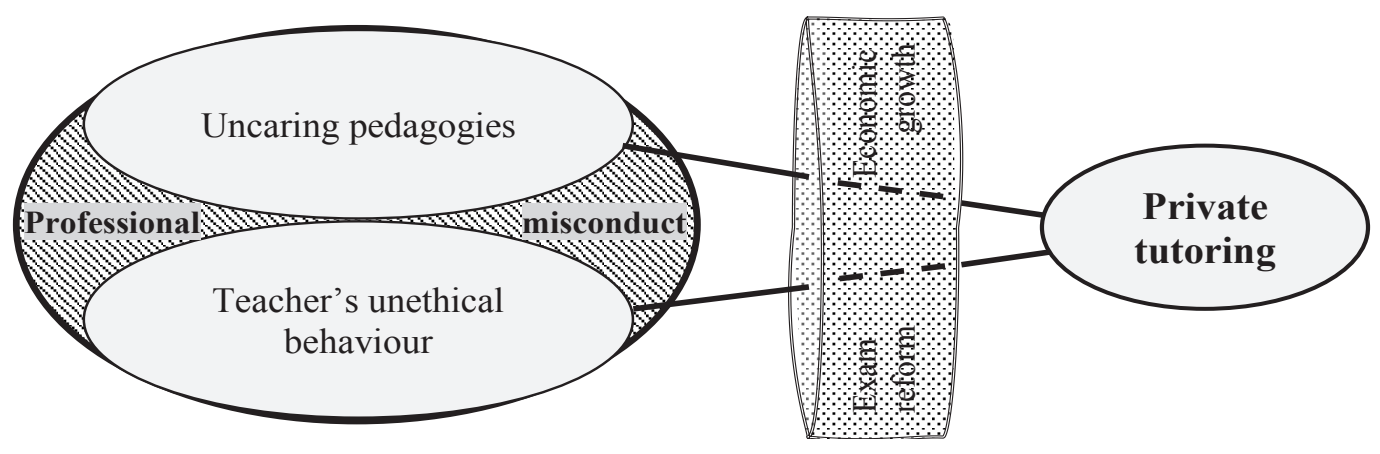

\section{Materials and Methods}

This study employed an explanatory sequential mixed method for data collection to question professional misconduct and PT in Cambodia. Quantitative data was first collected and followed by qualitative data to probe for in-depth reasons on the central phenomenon or any extreme cases (Creswell \& Creswell, 2018). Both phases for data collection were conducted online during school closures due to the COVID19 pandemic (MoEYS, 2020). Due to the fact that PT has a significant 
association with high-stakes examinations as well as the diploma-granting grades (Bray, 2009; Bray \& Lykins, 2012; Bregvadze, 2012; Dang, 2007; Elbadawy, Assaad, Ahlurg, \& Levison, 2007), this study narrowed its scope to $12^{\text {th }}$-grade students. This is the only grade of Cambodian general education where students are required to sit for the national examination.

The first phase of data collection started from late March to late April 2020. The online survey was sent out through social media applications to six $12^{\text {th }}$ grade classes, which were chosen by a cluster random sampling method, in all three urban upper secondary schools located in a province whose poverty rate (17.7\%) was a median of other 23 provinces in Cambodia. According to the Cambodian Ministry of Planning's data on Identification of Poor Household, as cited by Sok and Chhinh (2018), Phnom Penh Capital with a poverty rate of $9 \%$ and another province having a poverty rate of $37.1 \%$ were considered as outliers. Thus, they were removed prior to the research site selection process.

The survey questionnaire consisted of 16 statements $(\propto=.826)$ that were used to seek Cambodian $12^{\text {th }}$ graders' perceptions of their teachers' uncaring pedagogies and unethical behaviour during mainstream hours as well as of their mainstream schools. There were 9 statements about uncaring pedagogies starting from statement 2 to 9 and 12. Four statements were related to teachers' unethical/ethical behaviour, namely statements $1,10,11$ and 13 while the last three statements were about their schools. Participants were asked to choose one out of the five scales (strongly disagree $=-2$, disagree $=-1$, neutral $=0$, agree $=+1$ and strongly agree $=+2$ ) for each statement which best represented their perceptions. Before this, respondents were asked to estimate the percentage of their classmates who were taking PT during $12^{\text {th }}$ grade by selecting one choice $10 \%, 1-20 \%, 21-40 \%$, $41-60 \%, 61-80 \%, 81-100 \%$, Don't know) that applies to them. This scale was adopted from Bray and Kwo $(2015$, p. 174). The questionnaire was translated into Khmer (local language) and proofread by the researcher's colleagues who specialized in Khmer subject for feedbacks mainly in terms of content before it was sent to the participants. As a result, 93 tutees, accounting for $37.50 \%$, out of the total 248 twelfth graders responded to the survey. Twenty-seven respondents declared that both they and their parents were willing to participate in the interviewing stage. Prior to the data analysis, collinearity and reliability were checked and calculated (refer to Appendix A).

After obtaining results from the survey, the researcher conducted online semi-structured interviews during May and June 2020 to probe the central phenomenon and explain the descriptive results. Informants were from different educational stakeholder groups as well as tutoring actors as seen in Table 1. Interviewed tutees were randomly selected from the questionnaire among those who stated to voluntarily participate in the next process. Then the researcher conducted interviews with each tutees' parent separately. Since there was no data/record available about tutors, snowball sampling was done to select teachers as a tutor in each selected school. The first tutor in each school was introduced by one of the tutees in that school. In an attempt to seek if schoolteachers used their authority to force students to opt for PT, one school administrator from each selected school was invited to be the informant. As Page (2016) explains that despite teachers' misbehaviours being covertly performed, school administrators were still aware of the same. Consent forms to record (video calls) and use data were received from all interviewees.

Table 1: Types and Number of Samples

\begin{tabular}{ccc|cccc}
\hline $\begin{array}{c}\text { School } \\
\text { ID }\end{array}$ & $\begin{array}{c}\text { Total selected } \\
\text { students }\end{array}$ & $\begin{array}{c}\text { Returned } \\
\text { surveys }\end{array}$ & & & Informants for interviews $(n=24)$ \\
\cline { 2 - 7 } & total & Tutees & tutees & $\begin{array}{c}\text { tutee's } \\
\text { parents }\end{array}$ & tutors & $\begin{array}{c}\text { school } \\
\text { administrators }\end{array}$ \\
\hline US1 & 83 & 22 & 2 & 2 & 3 & 1 \\
US2 & 75 & 26 & 2 & 2 & 3 & 1 \\
US3 & 90 & 45 & 2 & 2 & 3 & 1 \\
\hline & 248 & $(n=93)$ & 6 & 6 & 9 & 3 \\
\hline
\end{tabular}


Prior to the content analysis stage, recorded interviews were transcribed, and transcripts were verified with some informants in the event the researcher would like to clarify some information or some local dialects. Two fundamentals of content analysis - conceptual and rational analysis, were used. Conceptual content analysis was employed to code concepts based on words and phrases frequently appearing in the scripts. Then rational content analysis was used to examine the relationship of the analysed concepts (Busch, et al., 2012).

\section{Results}

This paper aims to revisit Cambodian $12^{\text {th }}$ graders' perspectives on professional misconduct in PT. Results from the survey followed by interview responses will be presented. Furthermore, those results will be compared to findings from previous studies in this section.

\section{Percentage of Tutees and Investment}

\section{Figure 2. Estimated Percentage of Students Opting for PT}

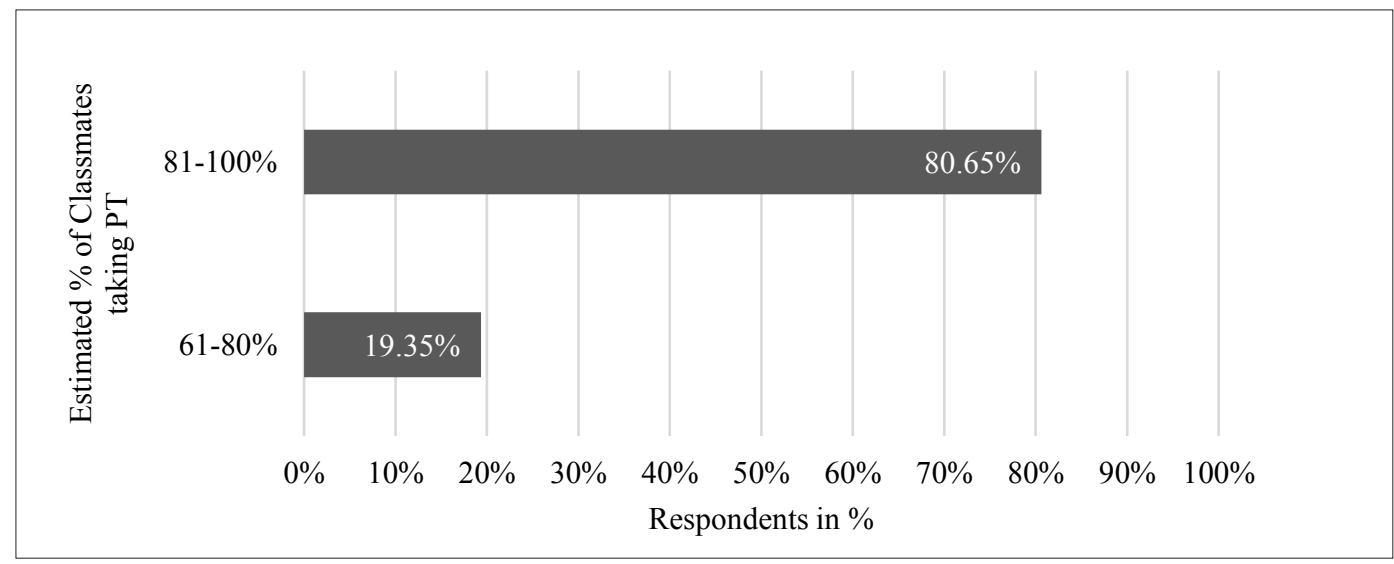

Figure 2 illustrates that majority of Cambodian grade 12 students invested in PT. This finding was aligned with that of previous studies in other contexts such as Vietnam and Egypt (Dang, 2007; Elbadawy, et al., 2007). About $81 \%$ of the respondents claimed that $81-100 \%$ of their classmates opt for PT while the remaining $19 \%$ responded that $61-80 \%$ of their classmates opt for PT. These results indicated that most students tended to view PT at this grade as mandatory for them to succeed in the national examination although they had to invest both time and money (Edwards, et al., 2019). Students in the social science strand spent about 40 hours in PT per month whereas their peers in the science strand spent about 100 hours per month. This required households to spend about US\$ (Dollars) 10 to US\$25 (US\$1=4,000 Cambodian Riel) per child per month on average for PT excluding English tutoring.

This [year] is my exam year. I have to take PT [...]. I am taking [PT] five subjects. I study mathematics, Physics and Chemistry for one hour per day, and I study only 2 days per week for Khmer [literature and composition] and Biology by taking 2 hours in a row for one day. [...] I pay 1,000 Riels (US\$.25) per hour for all [tutoring] subjects. (tutee [science] 3)

[...] I spend 3 hours and 3000 Riels (US\$.65) per day for PT. I am taking only Khmer and mathematics, but I have two [tutoring] classes in mathematics. Teachers rarely teach on Saturday [...]. (tutee [social science] 2) 
It is worth noting that, starting from 2010/2011, it is mandatory for Cambodian students to choose one of the two learning strands, namely Science (e.g., Physics, Chemistry, Biology) and Social Science (e.g., History, Geography, Moral Civics), during their second semester in $10^{\text {th }}$ grade (MoEYS, 2010). A household whose child followed the science strand seemed to spend more than double the total expenditure for PT which was paid by their peers having a child in the social science strand. This is due to the fact that students following the science strand had to take science and mathematics tests which were said to very challenging compared to their peers in the social science strand (Kao \& Shimizu, 2020). Even though the main aim of the current study is not to distinguish the different amount of time and money spent for PT by students in each learning strand, the results tended to nest inside the previous literature and shed light for further study.

This study echoed similar findings to that of Heyneman (2011) and Bray \& Kwo (2014). Parents were willing to invest in PT hoping that this would help their children succeed in their studies as well as secure their future. However, some parents admitted that PT would financially burden them if they had to pay for more than one child simultaneously. This could be implied that the family size seemed to influence PT consumption of the children like in the contexts of Vietnam and South Korea (Dang, 2007; Kim \& Park, 2010; Kim \& Lee, 2010).

I am not sure how many hours my child takes PT per day or week. [...] I pay around 100,000 Riel (US\$25) per month. [...] I think it [this amount] is fine for one child [emphasis by interviewee], but if that for 2 or 3 at same [diploma-granting grade], I don't think I may be able to afford. [...] I don't mind this because it is for my child's future. (parent 3)

I don't know [about my child's PT]. I just know that I gave him 5,000 [Cambodian] riels per day. He [child] said he pays 3,000 riels for PT and 2,000 riels for something else. [...] this amount is not much [emphasis of interviewee] when thinking about my child's future. (parent 2)

\section{Students' Perceptions of Teachers in Mainstream Schools}

The students perceived that teachers treated every student fairly and teachers did not force them to opt for PT. However, they thought that the central focus of the teachers was to complete the annual teaching plan according to the set curriculum rather than caring about students' understanding during the mainstream classes.

As seen in Figure 3, about $83 \%$ of the respondents highlighted that their teachers behaved fairly during examinations towards both tutees and non-tutees (statement 1). This could be implied that teachers seemed to apply one rule for all in every school-based examination. Consistently, almost all tutees (except tutee 9) acknowledged that teachers were fair and strict during the school-based examinations. This response was, additionally, echoed by all tutors during the interviews.

On the one hand, this finding seemed to contradict previous studies in the same context (i.e., Bray, et al., 2016; Bray, et al., 2018; Bray, et al., 2019; Edwards, et al., 2019; Maeda, 2019). On the other hand, this study tended to propose a new thought towards teacher's unethical behaviour during examinations. This positive behaviour change seemed to be swayed by examination reform especially when school-based examination results would no longer contribute towards the result of the national examination.

As I've observed, every teacher is really strict. I think during the [school-based] examinations, teachers are as strict as in the actual (national) examination. Teachers will deduct scores from or give zero scores to any student who cheats or asks each other during the examination. I myself experienced this [score deduction] [...]. (tutee 1) 
Figure 3. Students' Perceptions of Teachers at Mainstream School

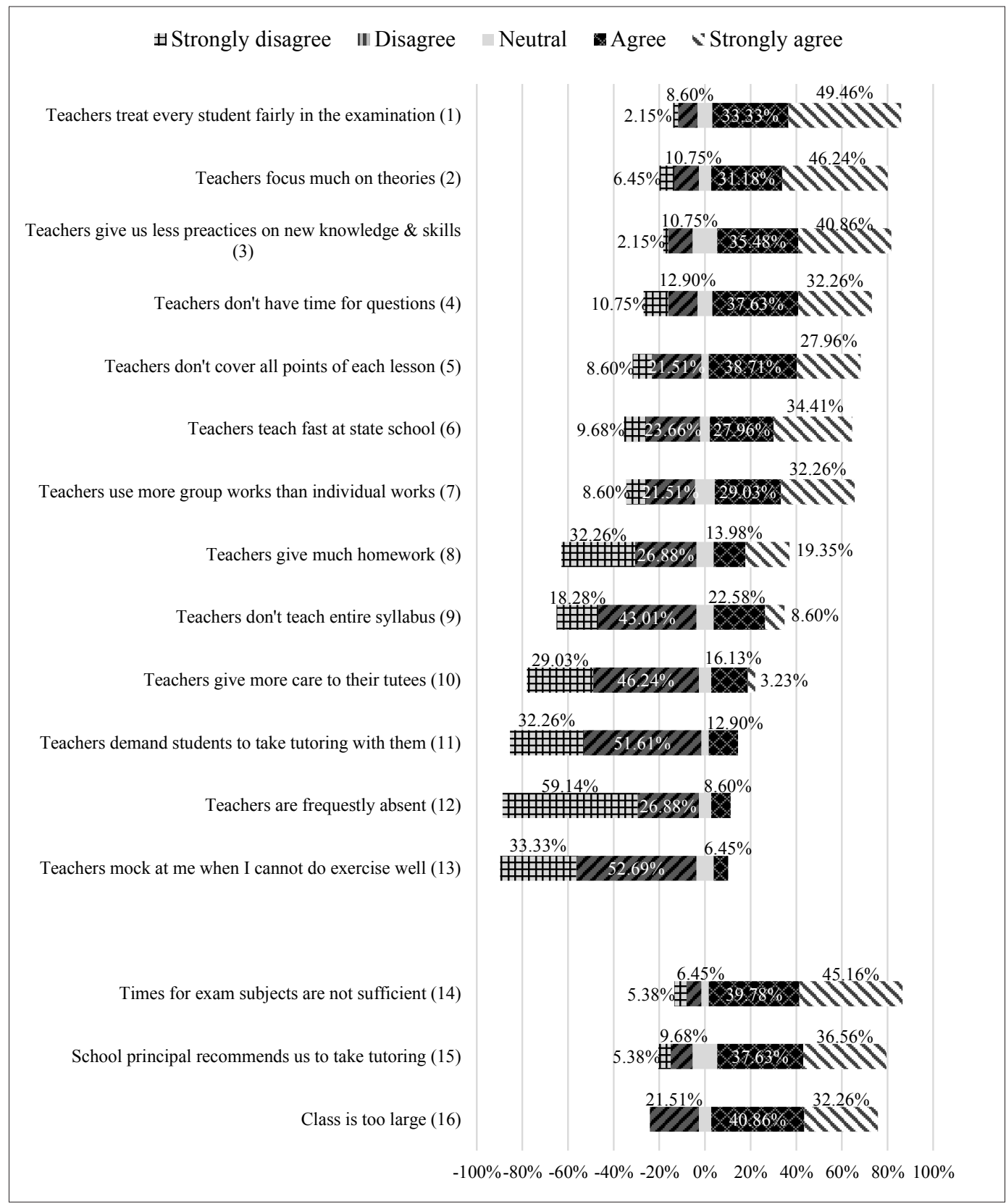

[...] teachers are really strict [emphasis of interviewee], and I sometimes feel that teacher is like two different persons. $\mathrm{S} /$ he is so funny and gentle during teaching hours, but so serious during [school-based] examinations. I cannot even move my head. (tutee 5)

Teachers also explained ways to promote their tutoring classes. Doing their best to help students learn during the mainstream hours as well as to support them more during tutoring classes were effective marketing strategies after the examination reform. The teacher whose former tutees obtained better grades during the national examinations would be approached by more students. 
Before [the examination reform] some teachers may have given some hints to their tutees about the tests/questions. Sometimes, they use the same exercises with different value or wording for the tests. Now [it] is not like before [the examination reform]. It doesn't work (help increase number of tutees) if we do so [...]. We have to teach them with care during mainstream hours. (tutor 2)

The main purpose of students to take to PT is to build their real ability and skills for examinations. They go to teachers who can help them to learn with quality. I think to have more tutees, we [teachers] need to use materials from different sources and help them understand better at both mainstream and tutoring classes. The best strategy is to ensure our tutees gain better grades in the national exam. (tutor 8 )

Regarding the concern about uncaring pedagogies, the majority of respondents agreed with the six statements ( 2 to 7 ) but disagreed with two statements ( 8 and 9 ). Teachers tended to shorten lessons by presenting only theory/formula and leaving some parts of lessons as well as to reduce the time for practice and individual interactions including time for questions. These descriptive results were in line with the previous studies (i.e., Bray, 1999a; Brehm \& Silova, 2014; Dawson, 2009).

On the contrary, this current study qualitatively unveiled two main factors affecting uncaring pedagogies at mainstream schools. Tutors and tutees as well as school administrators seemed to have the same opinion on the notion of uncaring pedagogies. One of which was less instructional time for core examination subjects. About $85 \%$ of respondents confirmed that time for core examination subjects was not sufficient enough (Statement 14). This was likely to contribute towards increasing PT demand (Bray, et al., 2016; Kobakhidze, 2015). From 2010/2011, regardless of the learning strand, Cambodian upper secondary school students have five core examination subjects, taking 17 hours out of 32 hours per week for 14 subjects (MoEYS, 2011). In 2016, MoEYS also released its latest curriculum framework by increasing instructional time for core examination subjects to 21 hours (MoEYS, 2016). However, this framework could not be implemented due to some challenges. It is worth highlighting that the issue of instructional time was originated from the national curriculum rather than the teacher absenteeism in this study. Evidently, most respondents (86\%) reported that their teachers were rarely absent at the mainstream schools (statement 12). All tutors explained that they tended to save time as much as they could for the lessons, or they were not able to complete the entire syllabus. Consistently, there were a higher percentage of tutees (62.37\%) who agreed with statement 6: teachers teach fast at state school.

[...] content and number of teaching hours do not match well. We will be blamed when being unable to complete the [annual teaching] plan. Thus, we cut some parts [of lessons] and explained main points briefly with some exercises for them to practice. (tutor 2)

[...] school requires us to use a learner-based [approach]. It takes much time. Group work is not effective because class is too big (40-50 students). Students need to understand every lesson very clearly because they are in the diploma-granting grade. (tutor 7)

Learning hours [for examination subjects] are not enough. Teachers cannot explain us precisely. [...]. Only choice we can do is to go to private lessons, so we can learn more, at least 4 hours per week in each subject. (tutee 4)

Another key factor was a learner-based approach. This teaching approach was reported as being more time-consuming than a teacher-based one in Lithuania (Būdienè \& Zabulionis, 2006). About $61 \%$ of respondents reported that teachers used group work more frequently than individual works during the mainstream hours (statement 7). On the one hand, teachers confessed that group work could help them broadly brush upon the contents despite knowing that students would not able to 
probably grasp all the contents. They, therefore, would not be blamed for staying behind the teaching plan. This finding echoed that of the Cambodian Education Sector Support Project (CESSP, 2006).

[...] the learner-centred approach takes too much time. Group work can help us to complete the lessons. We assign tasks to students and they will report their results. However, they could not understand clearly although we can catch up with our [teaching] plan. (tutor 3 )

On the other hand, this study unveiled that both teachers and students as well as school administrators perceived that the teacher-based approach was more effective with diploma-granting graders than was the learner-based approach.

Not only for my subject (physics), but also others, students can understand well [emphasis of the interviewee] at tutoring classes. We can focus on the same things until students can understand very well. Also, we follow our way of teaching (teacher-based approach) [emphasis of the interviewee]. No one blames us because it is our time [...]. (tutor 3 )

[...] I prefer more explanation from teachers rather than group discussion. The discussion is good, but it is not good for me for [the national] examination. It works with other grades but not this [ $\left[2^{\text {th }}\right]$ grade, I think. I need to understand every lesson clearly [...]. (tutee 6)

Furthermore, this study revealed that school administrators tended to recommend students to opt for PT and suggest teachers spare time to provide PT owing to the two issues above as well as a large class size in mainstream schools. On the contrary, Kobakhidze's (2014) study unveiled that teachers were the ones to recommend and persuade students and their families for PT by boasting the benefits of increased instructional time and individual interaction.

During the morning or afternoon assembly for the national anthem, I frequently remind them of the [national] examination, and I encourage them (all graders) to spare their time for private tutoring. [...] but I informed them that they can study with any teacher or anywhere they feel comfortable. (administrator 1 )

This implies that, in addition to parents and students, administrators also do not seem to trust the quality of education being provided in mainstream schools. About $74 \%$ of respondents reported that their school principals recommended them to opt for PT (statement 15) and about $73 \%$ complained about large class size at the mainstream schools (statement 16 ).

[...] I used to have this kind of feeling when I was a classroom teacher [of mathematics]. I presented only formula and gave some exercises to practice. Sometimes I was still behind the [teaching] plan. [...] I know it is not easy to use a learner-based approach. It takes much time but not really effective with $12^{\text {th }}$ graders and with this large class size. It may work with other (non-diploma-granting) grades. (administrator 2)

[...] Currently, to pass [the national examination] is not easy, they (students) must be qualified enough. Here [at mainstream school], [there are] many lessons but time is less, I almost always insist on them [teachers and students] to spare time for PT. Some teachers don't want to teach [PT] because their living is good enough or they need time to help their family business. (administrator 3 )

Unlike previous studies, this current study unveiled that teachers did not use their authority to force their students to take PT with them. Evidently, about $84 \%$ of respondents disagreed with statement 11 - teachers demand students to take tutoring with them. Tutees also claimed that they were aware of the challenging level of exercises in the national examination. Therefore, they were willing to invest their personal time and money. It was noted that students who followed the 
social science strand tended to opt for fewer tutoring subjects than their peers following the science strand. They took only Khmer literature and mathematics. They could learn other core examination subjects on their own because those subjects need only memorisation skills.

Opting for tutoring is our choice because it is about our examinations and future. We can study with any teachers we prefer. In my case, I am taking [PT] with my own teacher only for Khmer literature. Teachers don't mind with whom we are studying [PT]. They are happy when we are qualified and pass the [national] examination. I agree that a few years ago I did not feel good if I did not study PT with my own teachers. (tutee 6)

My teacher [Khmer literature] did not want to teach PT. We insisted him to spare time for us. Teachers don't mind whether you study PT with them or with others. Teachers just want us to be qualified to pass [the national examination]. Some teachers, for example, my teacher of mathematics, don't have time [to offer PT] for us. They teach special tutoring classes (oneto-one/small-group tutoring). (tutee 2)

Although only about $6.45 \%$ of tutees who admitted that teachers mocked them when they were not able to do exercises well (statement 13), one school administrator admitted that some teachers still favour more tutees and annoy non-tutees or tutees of other teachers especially when solving exercises during the mainstream hours. Similarly, one tutee stated that teachers provided their own tutees clarification individually after school-based examinations although about $75 \%$ of tutees reported that teachers cared about everyone (statement 10 ).

It is not easy to stop this (forcing students to take PT). In my school, almost every year, I got about 2 or 3 complaints from parents and students. Teachers blamed non-tutees or tutees with another teacher before their classmates when they are not able to solve [homework or practical] exercises well. (administrator 2)

[...] teachers do not act fairly especially after returning the examination results. Teachers spend time explaining their tutees individually during the mainstream class rather than explaining to everyone. (tutee 9)

\section{Conclusion and Implications}

The purpose of this paper is to gain insights into the central phenomenon of PT demand through Cambodian twelfth graders' perceptions of their teachers' professional misconduct during mainstream classroom hours. The results proposed that PT may become a norm among urban twelfth graders and their parents as the middle-class population keeps growing. However, family size may reduce PT consumption. Contextually, the households whose child followed the science strand tended to pay more than their peers whose child was in the social science strand. Furthermore, the findings pointed out that PT demand was impacted mainly by uncaring pedagogies rather than teacher's unethical behaviour.

Concerning uncaring pedagogies, this study identified that teachers seemed to be encouraged by two phenomena, namely lack of instructional time and impacts of learner-based approach at the mainstream schools. These phenomena were, furthermore, seen to encourage teachers to engage in PT. In order not to be blamed, teachers attempted to limit interactions and explanations despite knowing that students would not be able to grasp all contents being taught. Their main focus was to complete the assigned syllabus within the given instructional time. Therefore, students and parents invested their time and money for PT to strengthen knowledge and skills for the national examinations. Students having the capability to pay are able to go through the same content twice or in a proper way in which the syllabus should be taught effectively. On the contrary, students who are unable to pay for PT may be pushed at a disadvantage. 
A learner-based approach may be effective in learning; however, this study unveiled that this approach did not seem to work effectively with Cambodian students who were in diploma-granting grades. The findings imply that there may be some mismatch between how students were taught in class and the type or level of difficulty in exercises in the national examinations. Along the same line, Chey and Khieu's (2017) study pointed out that national examination tests in 2015 measured only remembering and understanding skills which relate more to the teacher-based approach. However, students in mainstream schools were taught through the learner-based approach (i.e., group works and discussion). This mismatch may contribute towards increasing PT demand among such group of students who aim to increase their capability for the national examinations.

The examination reform indicated positive contributions towards minimizing teacher's unethical behaviour during learning activities and school-based examinations in this empirical study. The reform can be seen, additionally, to expand the tutoring market and may gradually move PT towards a free market. Students gained more freedom to opt for tutors of their choice. Additionally, the tutoring market of teachers whose former tutees obtained good grades in the national examinations may be expanded. They are named as 'best tutor' in the Cambodian context.

Cambodia may be similar to other countries which are using a 'discouragement' strategy to regulate PT. However, this strategy meant to manage teachers' PT engagement did not seem to work in the Cambodian context. Some previous studies on PT in Cambodian and other contexts unveiled similar findings where teachers still involved in professional misconduct for personal gains. Professional misconduct may downplay the educational quality in the mainstream system. Gaining insights into teachers' professional misconduct may navigate educators and policymakers to the right focus. This empirical study, therefore, proposed to look at 'professional misconduct' from 2 perspectives: teacher's unethical behaviour and uncaring pedagogies, when addressing the issue of the relationship between teachers' professional misconduct and PT. Cambodia may be a significant example of this concern. It is worth acknowledging that Cambodia made a great change in teachers' payment and implemented a critical reform in examination. This can be argued that these could only fix teacher's unethical behaviour and gradually push PT towards a free market for those who are able to afford the same. However, uncaring pedagogies seemed to be safe to practice with common excuses - lack of instructional time and learner-based approach. Along the same line, these empirical pieces of evidence aim to alert the personnel at the central level as well as policymakers to consider maximising instructional hours for core examination subjects and simultaneously reducing hours of other subjects. Additionally, teachers should be given the freedom to choose appropriate teaching pedagogies that best fit their students' needs. To provide policymakers and implementers with more benefits, future studies should target a larger number of schools, extend to rural areas as well as employ on-site data collection. This study used the online survey which had some limitations in terms of participants' response time and limited capacity to generalise the findings.

\section{References}

Banfield, S., Richmond, V., \& McCroskey, J. (2006). The effect of teacher misbehaviors on teacher credibility and affect fro the teacher. Communication Education, 55(1), pp. 63-72. doi: $10.1080 / 03634520500343400$.

Barron, L. (2014, September 08). Meet the Man Behind the exams. Available at https://www. phnompenhpost.com/national/meet-man-behind-exams?fbclid=IwAR2cpjH6kDHyG5RkTdw zyuparPWqdnU5enj8kd5dhwT1dcXBb6f9b7QFL7g[Accessed 20 July 2019].

Betweli, O. (2013). The nature of teacher professional miscoduct in Tanzanian public primary schools: The case of Sumbawanga municipal and rural districts. International Journal of Education, 5(1), pp. 81-93. doi: 10.5296/ije.v5i1.3291.

Biswal, B. (1999). Private tutoring and public corruption: A cost-effective education system for developing countries. The Developing Economies, 37(2), pp. 222-240. 
Bray, M. (1999a). The Private Costs of Public Schooling: Household and Community Financing of Primary Education in Cambodia. Paris: International Institute for Education/UNESCO.

Bray, M. (1999b). Shadow Education System: Private Tutoring and its Implications for Planners. Paris: UNESCO International Institute of Educational Planning (IIEP).

Bray, M. (2003). Adverse Effects of Private Supplementary Tutoring: Dimensions, Implications and Government Responses. Paris: International Institute for Educational Planning \& UNESCO.

Bray, M. (2009). Confronting the Shadow Education System: What Government Policies for What Private Tutoring? Paris: UNESCO International Institute for Educational Planning.

Bray, M. (2013). Shadow education: Comparative perspectives on the expansion and implications of private supplementary tutoring. Procedia-Social and Behavioral Sciences, 77, pp. 412-420. doi: 10.1016/j.sbspro.2013.03.096.

Bray, M., \& Bunly, S. (2005). Ballancing the Books: Household Financing of Basic Education in Cambodia. Hong Kong: Comparative Education Research Centre, The University of Hong Kong.

Bray, M., Kobakhidze, M. N., Liu, J., \& Zhang, W. (2016). The internal dynamics of privatised public education: Free-charging supplementary tutoring provided by teachers in Cambodia. International Journal of Educational Development, 49, pp. 291-299. doi:10.1016/j. ijedudev.2016.04.003.

Bray, M., Kobakhidze, M. N., Zhang, W., \& Liu, J. (2018). The hidden curriculum in a hidden marketplace: Relationships and values in Cambodia's shadow education system. Journal of Curriculum Studies, 50(4), pp. 435-455. doi: 10.1080/00220272.2018.1461932.

Bray, M., \& Kwo, O. (2014). Regulating Private Tutoring for Public Good: Policy Opinions for Supplementary Education in Asia. Hong Kong: Comparative Education Research Centre (CERC) \& UNESCO Asia Pacific Regional Bureau for Education.

Bray, M., \& Kwo, O. (2015). Designing and implementing mixed approaches to shadow education research: Experiences and lessons in Hong Kong. In M. Bray, O. Kwo, \& B. Jokić (Eds). Researching Private Supplementary Tutoring: Methodological Lessons from Diverse Cultures. Hong Kong: Springer \& Comparative Education Research Centre (CERC), The University of Hong Kong, pp. 149-178.

Bray, M., Liu, J., Zhang, W., \& Kobakhidze, M. N. (2019). (Mis)trust and (abuse of) authority in Cambodian education: Parallel lessons in the shadow. In M. Schüpbach, \& N. Lilla (Eds), Extended Education from an International Comparative Point of View. Wiesbaden, Germany: Springer VS, pp. 7-21. doi:10.1007/978-3-658-27172-5.

Bray, M., \& Lykins, C. (2012). Shadow Education: Private Supplementary Tutoring and its Implications for Policy Markers in Asia. Mandaluyong, Philippines: Asian Development Bank.

Bregvadze, T. (2012). Analysing the shadows: Private tutoring as a descriptor of the education system in Georgia. International Education Studies, 5(6), pp. 80-89. doi: 10.5539/ies.v5n6p80.

Brehm, W. (2015). The structure and agents enabling educational corruption in Cambodia shadow education and the business of examinations. In Y. Kitamura, D. Edwards, C. Sitha, \& J. Williams (Eds), The Political Economy of Schooling in Cambodia. New York: Palgrave MacMillan, pp. 103-123.

Brehm, W., \& Silova, I. (2014). Hidden privatization of pubic education in Cambodia: Equity implications of private tutoring. Journal for Educational Research Online, 6(1), pp. 94-116.

Brehm, W., Silova, I., \& Tuot, M. (2012). The Public-Private Education System in Cambodia: The Impact and Implications of Complementary Tutoring. ESP Working paper No. 39. Budapest: Open Society Institute.

Būdienè, V., \& Zabulionis, A. (2006). Lithuania. In I. Silova, \& M. Bray (Eds), Education in a Hidden Marketplace: Monitoring of Private Tutoring. New York: Open Society Institute, pp. 211-235.

Busch, C., De Maret, P., Flynn, T., Kellum, R., Le, S., Meyers, B., Saunders, M., White, R., \& Palmquist, M. (2012). Content Analysis. Available at https://writing.colostate.edu/guides/pdfs/guide61. pdf[Accessed 02 July 2020]. 
Cambodian Education Sector Support Project (CESSP). (2006). Student Achievement and Education Policy: Result from the Grade Three Assessment. Phnom Penh: MoEYS.

Chey, C., \& Khieu, V. (2017). Cognitive domain, level of difficulty and topic distribution of the science stream in the national exit examination in Cambodia. Cambodia Education Review, 1(1), pp. 33-48.

Creswell, J., \& Creswell, J. (2018). Research Design: Qualitative, Quantitative, and Mixed Methods Approaches. California: SAGE.

Dang, H.-A. (2007). The determinants and impact of private tutoring classes in Vietnam. Economics of Education Review, 26(6), pp. 683-698.

Dang, H.-A. (2013). Private Tutoring in Vietnam: A Review of Current Issues and its Major Correlates (Policy Research Working Paper;No.6618). Washington, D.C.: The World Bank Development Research Group: Poverty and Inequality Team.

Dang, H.-A., \& Rogers, F. (2008). The growing phenomenon of private tutoring: Does it deepen human capital, widen inequalities, or waste resources? The World Bank Research Observer, 23(2), pp. 161-200.

Dawson, W. (2009). The tricks of the teacher: Shadow education and corruption in Cambodia. In S. P. Heyneman (Ed). Buying your Way into Heaven: Education and Corruption in International Perspective. Rotterdam, Netherlands: Senses Publishers, pp. 51-73.

Dawson, W. (2010). Private tutoring and mass schooling in East Asia: Reflections of inequality in Japan, South Korea, and Cambodia. Asia Pacific Education Review, 11, pp. 14-24. doi:10.1007/ s12564-009-9058-4.

Edwards, B., Le, H., \& Sustrarsic, M. (2019). Spatializing a global education phenomenon: Private tutoring and mobility theory in Cambodia. Journal of Education Policy, 35(5), pp. 713-732. do $\mathrm{i}: 10.1080 / 02680939.2019 .1610192$.

Elbadawy, A., Assaad, R., Ahlurg, D., \& Levison, D. (2007, October). Private and group tutoring in Egypt: Where is the gender inequality? Available at https://erf.org.eg/publications/private-andgroup-tutoring-in-egypt-where-is-the-gender-inequality/[Accessed 25 March 2020].

Hallak, J., \& Poisson, M. (2007). Corrupt Schools, Corrupt Universities: What can be Done? Paris: International Institute for Educational Planning (IIEP).

Hallak, J., \& Poisson, M. (2008). Academic fraud and quality assurance: Facing the challenges of the internationalisation of higer education. In G. Hemes, \& M. Martin (Eds), Accreditation and the Globle Higher Education Market (Vol. Policy Forum). Paris: International Institute for Educational Planning (IIEP), pp. 190-206.

Hanushek, E., \& Wößmann, L. (2007). The Role of Education Quality for Economic Growth. Working Paper No.4122. World Bank. Available at https://documents.worldbank.org/en/publication/ documents-reports/documentredirects?url=/external/default/WDSContentServer/WDSP/IB/20 07/01/29/000016406_20070129113447/Rendered/PDF/wps4122.pdf [Accessed 23 May 2020].

Heyneman, S. (2009). Buying your Way into Heaven: Education and Corruption in International Perspective. Rotterdam: Sense .

Heyneman, S. (2011). Private tutoring and social cohesion. Peabody Journal of Education, 86(2), pp. 183-188. doi:10.1080/0161956X.2011.561662.

Kao, S., \& Shimizu, K. (2020). Factors affecting Cambodian upper secondary school students' choice of science track. International Journal of Sociology of Education, 9(3), pp. 262-292. doi:10.17583/ rise.2020.4823.

Kelsey, D., Kearney, P., Plax, T., Allen, T., \& Ritter, K. (2004). College students' attributions of teacher misbehaviors. Communication Education, 53(1), pp. 40-55. doi: 10.1080/0363452032000135760.

Keng, C. (2009). Basic education in Cambodia: Quality and equity. In Y. Hirosato, \& Y. Kitamura (Eds), The Political Economy of Educational Reforms and Capacity Development in Southeast Asia: Cases of Cambodia, Laos and Vietnam. Netherlands: Springer, pp. 131-152.

Khiev, C., \& Ty, S. (2011, November 02). Strengthening the Quality of, and Building Confidence in, State Schools. Available at https://www.phnompenhpost.com/lift/strengthening-quality-andbuilding-confidence-state-schools[Accessed 12 October 2020]. 
Khy, S. (2019, October 28). Wages SettolncreaseforCivilServants. Availableathttps://www.khmertimeskh. com/654902/wages-set-to-increase-for-civil-servants/?fbclid=IwAR2AHjRUyUwqY_Kx2NF5Hu XYXn3UhCewhgYLbM5S4ABL4jbBxouQ882vTxA[Accessed 20 July 2019].

Kim, J.-H., \& Park, D. (2010). The determinants of demand for private tutoring in South Korea. Asia Pacific Education Review, 11, pp. 411-421. doi:10.1007/s12564-009-9067-3.

Kim, S., \& Lee, J.-H. (2010). Private tutoring and demand for Education in South Korea. Economic Development and Cultural Change, 58(2), pp. 259-296. doi: 10.1086/648186.

Kobakhidze, M. N. (2014). Corruption risk of private tutoring: Case of Georgia. Asia Pacific Journal of Education, 34(4), pp. 455-475. doi: 10.1080/02188791.2014.963506.

Kobakhidze, M. N. (2015). Shadow education research through TIMSS and PIRLS: Experiences and lessons in the Republic of Georgia. In M. Bray, O. Kwo, \& B. Jokic (Eds), Researching Private Supplementary Tutoring: Methodological Lessons from Diverse Cultures. Hong Kong: Comparative Education Research Centre (CERC), Springer, pp. 23-48.

Koyanagi, K. (2017, March 16). Cambodia's Teachers Cannot Afford to be Professional. Available at https://asia.nikkei.com/Economy/Cambodia-s-teachers-cannot-afford-to-be-professional?f bclid=IwAR3Ai5tbRI5oQvfFuaazfOh9hcnWUNcwgVHskKxb1Jg_NsGY850ZD1Q5X0o[Accessed 10 August 2020].

Kuch, N., \& Blomberg, M. (2014, April 08). Education Ministry to Delegate Junior High Exam to Schools. Available at https://english.cambodiadaily.com/news/education-ministry-to-delegate-juniorhigh-exam-to-schools-56015/[Accessed 20 July 2019].

Kwok, P. L. (2010). Demand intensity, market parameters and policy responses towards demand and supply of private supplementary tutoring in china. Asia Pacific Education Review, 11(1), pp. 49-58. doi:10.1007/s12564-009-9060-x.

Liu, J., \& Bray, M. (2020). Accountability and (mis)trust in education systems: Private supplementary tutoring and the ineffectiveness of regulation in Myanmar. European Journal of Education, 55(3), pp. 361-375. doi: 10.1111/ejed.12409.

Maeda, M. (2019). Exam cheating among Cambodian students: When, how, and why it happens. Campare: A Journal of Comparative and International Education, pp. 1-19. doi: 10.1080/03057925.2019.1613344.

Ministry of Education Youth and Sport (MoEYS). (2008). Ethics Code for the Teaching Profession. Phnom Penh: MoEYS.

MoEYS. (2009). Updating the Salary Wage per Unit for Civil Servants of the Kingdom of Cambodia (in Khmer). Phnom Penh: Cambodian Government.

MoEYS. (2010). Instruction on General Education Curriculum Implementation at Upper Secondary School, No. 23 moey.s.n.n (in Khmer). Phnom Penh: MoEYS.

MoEYS. (2011). Guideline for General Education Curriculum Implementation for Grade 11 \& 12. Phnom Penh: MoEYS.

MoEYS. (2013). Organization and Implementation for Upper Secondary General Education Certificate Examiniation No. 74 moeys.br.k (in Khmer). Phnom Penh: MoEYS.

MoEYS. (2016). Curriculum Framework of General Education and Technical Education. Phnom Penh: MoEYS.

MoEYS. (2019a). Updating the Salary Wage per Unit for Civil Servants of the Kingdom of Cambodia (in Khmer). Phnom Penh: Cambodian Government.

MoEYS. (2019b). Examination Preperation and Implementation at Upper Secondary Education No.155 moeys.br.k (in Khmer). Phnom Penh: MoEYS.

MoEYS. (2019c). Announcement on the Results of Upper Secondary School Examination in 2019 (in Khmer). Phnom Penh: MoEYS.

MoEYS. (2019d). Private Education Statistics \& Indicatiors 2018-2019 (in Khmer). Phnom Penh: MoEYS. MoEYS. (2019e). Public Education Statistics \& Indicators. Phnom Penh: MoEYS.

MoEYS. (2020). Early School Vocation for All Types of Educational Institutions (in Khmer). Phnom Penh: MoEYS. 
Mori, I., \& Baker, D. (2010). The origin of universal shadow education: What the supplemental education phenomenon tells us about the post modern institution ofeducation. Asia Pacific Education Review, 11, pp. 36-48. doi:10.1007/s12564-009-9057-5.

Page, D. (2016). The multiple impacts of teacher misbehaviour. Journal of Educational Administration, 54(1), pp. 2-18. doi: 10.1108/JEA-09-2014-0106.

Rumyantseva, N. (2005). Taxonomy of corruption in higer education. Peabody Journal of Education, 80(1), pp. 81-92. doi: 10.1207/S15327930pje8001_5.

Sok, S., \& Chhinh, N. (2018, September 11). Poverty Alleviation and Income Inequality in Cambodia: Balancing "Growth" and "Development". Available at https://theasiadialogue.com/2018/09/11/ poverty-alleviation-and-income-inequality-in-cambodia-balancing-growth-and-development/ [Accessed 12 December 2019].

World Bank. (2019). GDP Growth (annual \%) - Cambodia. Available at https://data.worldbank.org/ indicator/NY.GDP.MKTP.KD.ZG?locations=KH\&fbclid=IwAR1n1dy8BFkS2Kwn7iNF4F4Qb6209| ZB4Th3cXRzRVyGhMf-28NorRJAbnA[Accessed 29 October 2020].

Zhang, Q. (2007). Teacher misbehaviors as learning demotivators in college classrooms: A crosscultural investigation in China, Germany, Japan, and the United States. Communication Education, 56(2), pp. 209-227. doi: 10.1080/03634520601110104.

Zhang, Q., Zhang, J., \& Castelluccio, A.-A. (2011). A cross-cultural investigation of student resistance in college classrooms: The effects of teacher misbehaviors and credibility. Communication Quarterly, 59(4), pp. 450-464. doi: 10.1080/01463373.2011.597287. 


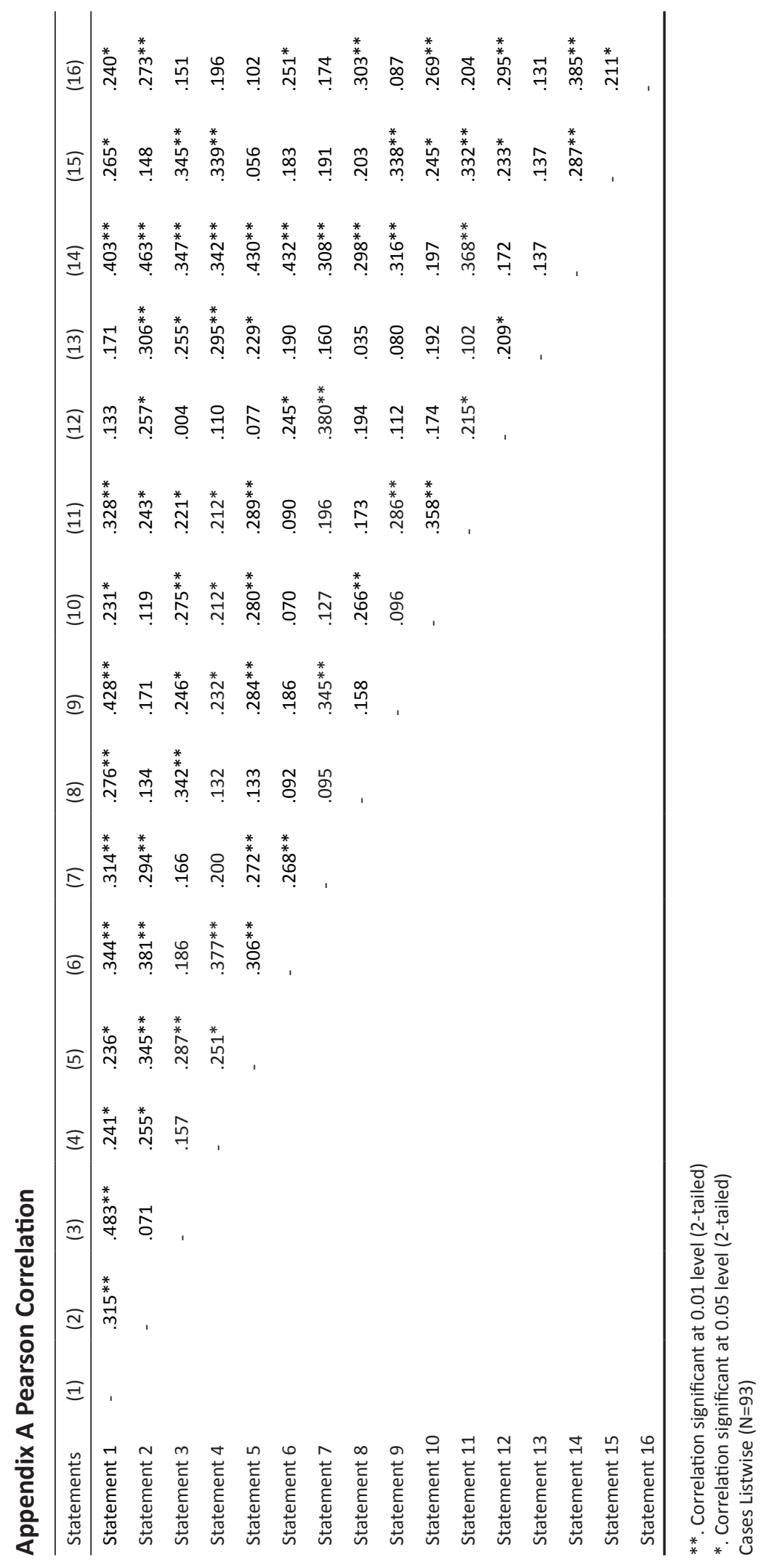


